\title{
APPLICATION OF THE MAKE A MATCH MODEL ASSISTED WITH ESAPI MEDIA TO IMPROVE STUDENTS' LEARNING OUTCOMES
}

\author{
Nita Yunda Sari ${ }^{1}$, Ika Oktavianti ${ }^{2}$, Deka Setyawan ${ }^{3}$ \\ ${ }^{1,2,3}$ Universitas Muria Kudus, Kudus, Indonesia
}

\begin{tabular}{|c|c|}
\hline Article Info & ABSTRACT \\
\hline Article history: & This study aims to describe the application of the model a make a match assisted by \\
\hline Received: 02-02-2021 & ESAPI media to improve student learning outcomes in grade IV SDN Wonoketingal \\
\hline Revised: $14-03-2021$ & 02. Classroom action research was conducted in class IV SDN Wonoketingal 02 with a \\
\hline Published: $10-05-2021$ & research subject of 20 students. This study uses design classroom action research from \\
\hline & Kemmis and MC. Taggrat and last for 2 cycles. The independent variable of this study \\
\hline Keywords: & study is student learning outcomes. Data collection methods used are qualitative and \\
\hline Make a match & quantitative data. The result showed an increase in mastery learning outcomes aspects \\
\hline ESAPI Media & of knowledge in the first cycle of $73.3 \%$ and an increase in the second cycle of $77.2 \%$ \\
\hline Learning Outcomes & in good qualifications. The completenese of both cycles is $3.9 \%$ with a good category. \\
\hline Elementary Students & This proves that the application of the make a match model assisted by ESAPI media \\
\hline
\end{tabular}

This is an open access article under the CC BY-SA license.

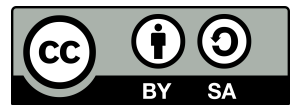

\section{Corresponding Author:}

Nita Yunda Sari,

Elementary Education Study Program, Faculty of Teacher Training and Education, Universitas Muria Kudus, Jl. Lkr. Utara, Kayuapu Kulon, Gondangmanis, Kec. Bae, Kabupaten Kudus, Jawa Tengah, Indonesia.

Email: nitayunda89@gmail.com

\section{INTRODUCTION}

Curriculum renewal changes learning that was originally teacher-centered to student-centered, which is able to develop student creativity and become more active students. At this time to develop the quality of education has been carried out by the government, one of which is using the 2013 curriculum method. The characteristics of the 2013 curriculum learning are thematic. Ardianti et al. (2018) state that thematic-based learning is integrated learning using themes to link multiple subject content so as to provide meaningful experiences to students. One example of lesson content in thematic learning is Social Studies and Bahasa Indonesia. Social studies learning emphasizes students memorizing the material while Bahasa Indonesia learning emphasizes students to read more so that students will feel bored more easily. One of the models and learning media that can be applied to improve student learning activities in social studies content and Indonesian is using the make a match model assisted by ESAPI media. The purpose of this study was to explain the improvement in the learning outcomes of fourth grade students of SDN Wonoketingal 02 using the make a match model assisted by ESAPI media.

Based on the results of observations made by researchers at SDN Wonoketingal 02 who received information that there are still many students who have difficulty receiving learning material so that the learning outcomes of $4^{\text {th }}$ grade students of SDN Wonoketingal 02 decline. Students are less active when learning takes 
place, don't dare to express opinions when the teacher asks questions. Therefore active, creative and fun learning is held which has an element of playing so that it can improve the learning outcomes of $4^{\text {th }}$ grade students at SDN Wonoketingal 02. This is in line with the opinion of Maulandhiyani et al. (2019) through the cooperative learning model type make a match, students driven to increase activeness; enthusiasm for learning; mastery of subject theory; cooperation which will directly increase student motivation and learning outcomes. In line with the research conducted by Siti Nur Nahdiyati entitled "Application of the Make A Match Method to Improve Social Studies Learning Outcomes in $3^{\text {rd }}$ Grade Students of SDN 1 Jenang Ponorogo", the reason researchers used this model was because the application of the model made a match more active students in learning so that it contained learning more meaningful because of direct student involvement.

Judging from the results of these observations, it is necessary to make improvements in the teaching and learning process in order to improve student learning outcomes. The fact of the low student learning outcomes is supported by the documentation that the researchers obtained in daily assessments of students in class. The learning outcomes of $4^{\text {th }}$ grade students of SDN Wonoketingal 02 in the first semester of the 2019/2020 academic year are still below the Minimum Completion Criteria (KKM) set by the school, that is 70. Based on the documentation, there are 204 th grade students of SDN Wonoketingal 02 which there are 10 students meet the KKM and 10 students have not reached the KKM. Based on these data, it shows that $50 \%$ of students have not fulfilled the KKM, while there are 12 students fulfills the KKM in Bahasa Indonesia subject and those who have not fulfilled the KKM are 8 students. The data shows that $40 \%$ of students have not met the KKM.

Based on the problems found, the researcher provides a solution, namely by using a fun model with a game element to convey the material, one of which is using the make a match model assisted by ESAPI media. According to Lorn Curran in Huda (2013) in this technique, students look for partners to learn a particular concept or topic in a pleasant atmosphere so that it can improve student learning outcomes. In line with the opinion of Deschuri et al. (2016) which states that by using the make a match model student will be more enthusiastic because the model has elements of game. In addition, students are directly involved in learning. The make a match technique is able to create interactive and active classroom conditions; to train students 'courage; to eliminate students' sense of boredom when learning takes place. Based on these reviews, the make a match model can be used as an alternative to improve student learning outcomes to take part in active and fun learning. Furthermore, the make a match model has a positive impact on the progress of student learning outcomes. This is because the make a match model invites students to be more active in looking for pairs of cards while learning about a topic in a fun learning atmosphere. Shoimin (2014) reveals that the make a match model is a model which requires student activeness to move actively to find a pair card that matches the question and answer cards on the card. Riyanti et al. (2018) state that the make a match learning model is a group learning model that invites students to understand the concepts and learning topics through the media of answer cards and question cards and in its implementation, it has a maximum time limit.

The learning process will be more enjoyable if in its process there are learning media which will certainly facilitate the activities. Learning media is a tool or intermediary that can connect or convey messages or information on learning materials from educators to students in the teaching and learning process (Erfan, Widodo, Umar, Radiusman, \& Ratu, 2020). Aqib (2016) states that learning media is used to convey messages so that it can make it easier for students in the teaching and learning process. In line with the opinion according to Sadiman (2010) stated that media is something that is used to transmit messages from sender to receiver so that it can stimulate thoughts, feelings, and attention so that the learning process occurs. Meanwhile, according to Wati et al. (2014) revealed that the media is a tool for transmitting messages from sender to receiver. The media that the researcher uses is the ESAPI media. The media is used to make it easier for the teacher to convey the material to be studied and of course it will make it easier for students to receive the material presented by the teacher.

Previous researchers stated that, ESAPI media is a medium that informs the traditional game "engklek" which is drawn on the banner and is played with "saruk". According to Oktavianti and Ratnasari (2017), the traditional game "engklek" is a traditional game with a jumping motion with one or two feet on a plot that is drawn on the ground. Meanwhile, according to Munawaroh (2017) states that the learning model using the game "engklek" has a goal that can develop aspects of child development, namely aspects of moral values, language, social emotional, and physical motoric aspects of children. Based on this description, the researcher took action by applying the make a match model assisted by ESAPI media to improve student learning outcomes. 


\section{RESEARCH METHOD}

The research approach used was classroom action research which consisted of 4 stages, namely planning, action, observation, and reflection. This research was conducted for 2 cycles, each cycle carried out for 2 times. This research was carried out on $204^{\text {th }}$ grade students of SDN Wonoketingal 02 in the 2019/2020 academic year. SDN Wonoketingal 02 is located at Jl. Demak.

Research data collection methods used test techniques and non-test techniques. The test that the researcher used was in the form of a description test. There are about 10 questions which was carried out at the end of the cycle. The test is used to determine student learning outcomes by applying the model and media chosen by the researcher as a solution to the problems that exist in SDN Wonoketingal 02, namely the application of the make a match model assisted by ESAPI media on Theme $6 \mathrm{Me}$ and My Goals. Meanwhile, non-test techniques, namely researchers use interviews, observation, and documentation. The indicators of success in this study are: 1) the teaching skills of teachers can be said to increase if the score obtained is $\geq 70$ with $70 \%$ classical completeness; 2) student learning activities can be said to increase if the score obtained is $\geq 70$ with $70 \%$ classical completeness. 3) an increase in learning outcomes can be said to increase if the value obtained is $\geq 70$ with $70 \%$ classical completeness.

\section{RESULT AND DISCUSSION}

The research used the make a match model assisted by ESAPI media carried out in 4th grade students of SDN Wonoketingal 02, Karanganyar District, Demak Regency. The problems found in SDN Wonoketingal 02 are that teachers still use CTL; the learning method is still conventional; teachers have not used innovative models and media; students have difficulty receiving learning; and students do not dare to express opinions when the teacher asks questions. The low student learning outcomes can be seen based on the daily scores of students in the previous theme with the number of students who completed the social studies subject was 10 students with $50 \%$ classical completeness and the Indonesian language subject got grade completeness, namely 12 students with $40 \%$ classical completeness with less criteria. Low student learning outcomes occur due to the lack of enthusiasm of students in paying attention to the subjects taught by the teacher.

The low student learning outcomes can be improved by using the make a match model assisted by ESAPI media. According to Fitriyah et al. (2018) stated that the traditional game of "engklek" is a traditional game of jumping on flat fields drawn on the ground, by drawing boxes then jumping with one foot from box to the next box drawn.

Researchers plan learning activities using the make a match model assisted by ESAPI media. This action is adjusted to the type of action used by the researcher, namely classroom action research (PTK) which consists of four stages, namely: planning, action, observation, reflex. At the implementation stage, it was carried out using the make a match model assisted by ESAPI media. To find out student learning outcomes, researchers used evaluation test questions in the form of essays that were adjusted to indicators of learning outcomes. The results of the research were obtained from the learning outcomes of theme 6 through the make a match model assisted by ESAPI media. The results of research in pre-cycle, cycle I and cycle II were obtained as follows:

Table 1. Improvement of student learning outcomes on each cycle

\begin{tabular}{llcccccc}
\hline \multirow{2}{*}{ Score } & \multirow{2}{*}{ Information } & \multicolumn{2}{c}{ Pre-cycle } & \multicolumn{2}{c}{ Cycle I } & \multicolumn{2}{c}{ Cycle II } \\
\cline { 3 - 8 } & & Frequency & Percentage & Frequency & Percentage & Frequency & Percentage \\
\hline \multirow{2}{*}{ Complete } & 11 & 55 & 14 & 70 & 17 & 85 \\
$<70$ & Not complete & 9 & 45 & 6 & 30 & 3 & 15 \\
Total & & 20 & 100 & 20 & 100 & 20 & 100 \\
Average & & 72 & & 73 & & 77 & \\
Minimum & & 52 & & 57 & & 63 & \\
Maximum & & 90 & & 87 & & 92 & \\
\hline
\end{tabular}

Based on Table 1, it can be seen that the results of student evaluation tests have increased in each cycle. The application of the ESAPI media-assisted make a match model to improve student learning outcomes can be seen from the average increase in Pre-cycle, cycle I and cycle II. The improvement of student learning outcomes from the results of the evaluation test is presented in the following picture. 


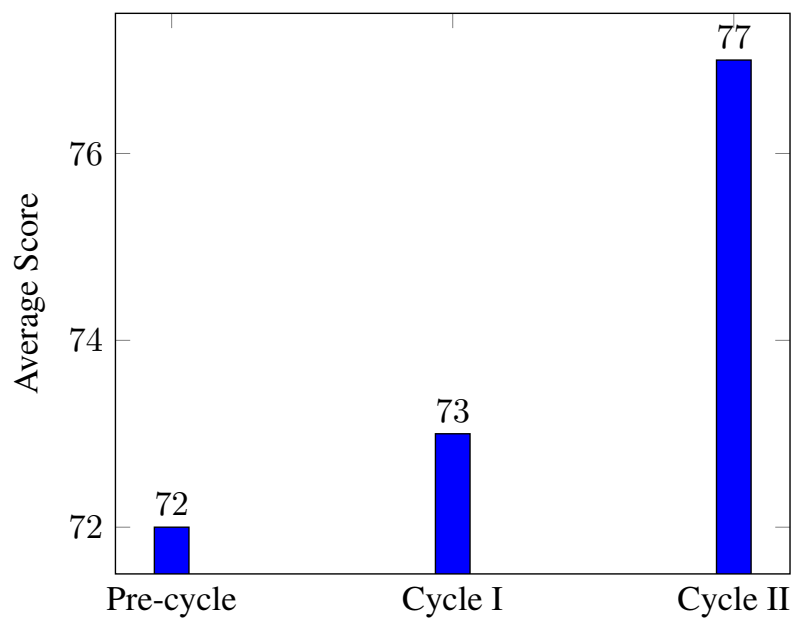

Figure 1. Student Learning Outcomes Comparison

Based on Figure 1, the results of the evaluation of the final test cycle 1 were obtained with the highest score of 86.7 and the lowest score of 56.6, the number of students completed as many as 14 students, the number of students who did not meet the KKM was 6 students. Overall, the average score of 73.3 with good criteria. There was an increase from pre-cycle to cycle 1.

The results of the second cycle test obtained results with the highest score of 91.7 and the lowest score of 66.7. The number of students completing as many as 17 students and the number of students that can't met the KKM as many as 3 students. Overall, the average score of 77.2 with good criteria. There was an increase from cycle I to cycle II. The percentage obtained has met the predetermined minimum limit of success indicators. This proves that the application of the make a match model assisted by the ESAPI media can improve the learning outcomes of fourth grade students of SDN Wonoketingal 02.

\section{CONCLUSION}

Based on the results of the research and discussion, it can be concluded that the increase in learning outcomes of $4^{\text {th }}$ grade students of SDN Wonoketingal 02, Karanganyar District, Demak Regency can be applied through the make a match model assisted by ESAPI media. This can be seen in the pre-cycle data, cycle I, and cycle II data. Based on the research results, it is suggested that SDN Wonoketingal 02 teachers apply the ESAPI Media Assisted Make A Match model to improve the learning outcomes of fourth grade students in a fun way of learning.

\section{REFERENCES}

Aqib, Z. (2016). Model-Model, Media, dan Strategi Pembelajaran Kontekstual (Inovatif). Bandung: Yrama Widya.

Ardianti, D. S., Ulya, H., \& Ismaya, E. A. (2018). Pakem dalam Kurikulum 2013. Kudus: Badan Penerbit Universitas Muria Kudus.

Deschuri, C., Kurnia, D., \& Gusrayani, D. (2016). Penerapan Model Kooperative Teknik Make a Match dengan Media Kartu Klop untuk Meningkatkan Hasil Belajar Siswa pada Materi Kenampakan Alam dan Buatan. Pena, 1(1), 361-370.

Erfan, M., Widodo, A., Umar, U., Radiusman, R., \& Ratu, T. (2020). Pengembangan Game Edukasi Kata Fisika Berbasis Android untuk Anak Sekolah Dasar pada Materi Konsep Gaya. Lectura: Jurnal Pendidikan, 11(1), 31-46.

Fitriyah, A., \& Khaerunisa, I. (2018). Pengaruh Penggunaan Metode Drill Berbantuan Permainan Engklek Termodifikasi terhadap Kemampuan Pemecahan Masalah Siswa Kelas VII. Journal of Medives: Journal of Mathematics Education IKIP Veteran Semarang, 2(2), 267-277.

Huda, M. (2013). Model-model Pengajaran dan Pembelajaran. Yogyakarta: Pustaka Pelajar.

Maulandhiyani, W. T., Mulyana, E., \& Azizah, D. N. (2019). Penerapan Model Pembelajaran Make A Match untuk Meningkatkan Hasil Belajar Siswa. Edusentris, 5(2), 114. doi:10.17509/edusentris.v5i2.298 
Munawaroh, H. (2017). Pengembangan Model Pembelajaran dengan Permainan Tradisional Engklek Sebagai Sarana Stimulasi Perkembangan Anak Usia Dini. Jurnal Obsesi : Jurnal Pendidikan Anak Usia Dini, 1(2), 86. doi:10.31004/obsesi.v1i2.19

Oktavianti, I., \& Ratnasari, Y. (2017). Permainan Monopoli Engklek Jelajah Budaya Pati Untuk Pembelajaran Tematik. Pendidikan Bahasa Dan Sastra Indonesia (PBSI) FKIP Universitas Muria Kudus, 63-71.

Riyanti, N. N., \& Abdullah, M. H. (2018). Penerapan Model Pembelajaran Kooperatif Tipe Make A Match untuk Meningkatkan Hasil Belajar IPS Siswa. Jurnal Penelitian Pendidikan Guru Sekolah Dasar, 6(4), $440-450$.

Sadiman, A. (2010). Media Pendidikan: pengertian, pengembangan, dan pemanfaatannya. Jakarta: PT. Raja Grafindo Persada.

Shoimin, A. (2014). 68 Model Pembelajaran Inovatif dalam kurikulum 2013. Yogyakarta: Ar-Ruz Media.

Wati, Y. R., Utomo, S. B., \& Redjeki, T. (2014). Efektivitas Metode Pembelajaran Kooperatif Tipe Team Assisted Individualization (TAI) dengan Media Komik Terhadap Prestasi Belajar Siswa pada Materi Hidrokarbon Kelas X SMA Negeri 1 Kartasura Tahun Pelajaran 2012/2013. Jurnal Pendidikan Kimia, 3(2), 16-21. 